\title{
The Nigeria's Debt- Growth Nexus: A Blessing or Burden?
}

\section{Christian Gbarawae NWIKINA \\ Ledum Moses GBARATO ${ }^{2}$ Joseph Jim MEEKOR ${ }^{s}$}

'Department of General Studies, School of Foundation Studies, Kenule Beeson Saro-Wiwa Polytechnic, Rivers State, Nigeria.

Email:conwikina@gmail.com Tel:08063779661

${ }^{2}$ Department of Finance $\mathcal{E}^{2}$ Banking, Faculty of Management Science, University of Port Harcourt, Nigeria. Email:Ledum4success@gmail.com Tel:0806310447s

${ }^{2}$ Department of Economics, Ignatius Ajuru University of Education, Port Harcourt, Nigeria.

Email:jimmeekor@gmail.com Tel: 08037912055

\section{Abstract}

The option of leveraging on recommendable borrowings does not only stimulate favourable economic growth but also offers meaningful upsurge in the financial position of parties involved. It is on this premise that prompted the essence to examine the Nigeria's debt- growth nexus: whether a blessing or burden, for the period 1981 to 2019. Secondary data from CBN statistical Bulletin were employed in the study. Using the Error Correction Model, the results reveal that, although debt servicing exerts negative relationship with economic growth, it is obvious that debt financing in Nigeria is a blessing as external and domestic debt stocks all exert positive influence on economic growth. However, only domestic debt stock is efficient enough to spur economic activities, which suggests that prudent employment of domestic debt which is not affected by exchange rate is a strong catalyst for rapid increase in economic activities in Nigeria. Therefore, having identified domestic debt as the linchpin of economic growth in Nigeria, the study recommends the choice for internally borrowed fund as the best benign financing option as well as its optimal utilization for meaningful commensurate economic activities. Also, recommendable threshold point of borrowing should strictly be adhere to, in order to avoid landing the economy into a state of onerous experience.

Keywords: External debt, Domestic debt, Debt servicing, Nominal GDP, Nigeria.

Citation | Christian Gbarawae NWIKINA; Ledum Moses GBARATO; Joseph Jim MEEKOR (2020). The Nigeria's DebtGrowth Nexus: A Blessing or Burden?. Economy, 7(2): 119-127. History:

Received: 21 October 2020

Revised: 17 November 2020

Accepted: 30 November 2020

Published: 14 December 2020

Licensed: This work is licensed under a Creative Commons

Attribution 3.0 License (cc)

Publisher: Asian Online Journal Publishing Group
Acknowledgement: All authors contributed to the conception and design of the study.

Funding: This study received no specific financial support

Competing Interests: The authors declare that they have no conflict of interests.

Transparency: The authors confirm that the manuscript is an honest, accurate, and transparent account of the study was reported; that no vital features of the study have been omitted; and that any discrepancies from the study as planned have been explained.

Ethical: This study follows all ethical practices during writing.

\section{Contents}

1. Introduction

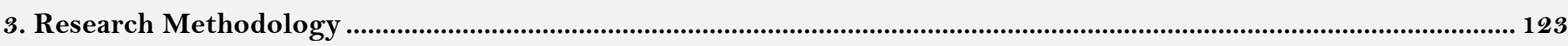

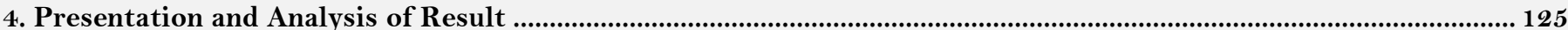

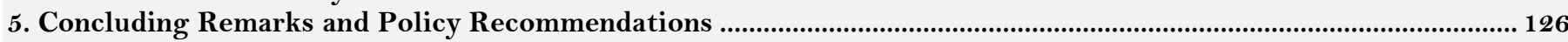

References 


\section{Contribution of this paper to the literature}

As a contribution to knowledge, this paper unveils that output level of goods and services in Nigeria has been greatly sustained by domestic debt employed. As it portrays efficient influence unlike external debt that favoured the economy marginally.

\section{Introduction}

Standard of living, level of employment and output level of goods and services in a country are greatly determined by the country's management of public finance (Rafindadi \& Musa, 2019). An efficient revenue generation sources as well as its allocation and utilization, lubricate economic activities, a sine qua non for economic growth and development.

However, differences in natural endowment, technology, human capital development and value system have emanated the country-ranking into developed, developing and underdeveloped economies, where the less counterparts aspire to gain higher economic prominence. This astute quest alongside the need to accommodate increasing population with its attendant challenges necessitates incessant increase in public expenditure. Consequently, subjecting the deficit-economic countries, mostly, the underdeveloped and developing countries to greatly rely on the surplus-economic countries for aids, grants and loans in financing public expenditures (Adepoju, Salau, \& Obayelu, 2007; Fasoye, 2018).

Therefore, Nigerian being an emerging economy is not left out in both internal and external borrowing in order to finance her public expenditures. Although, public borrowing is not bad, especially when there is prudent utilization to create productive assets and contagious economic-benefiting environment (Ngassam, 2000), however, on the contrary, effect of public debt becomes devastating not only to present generation but also unborn generation. Effort on this thoughtful consequence has led to the establishment of Debt Management Office in Nigeria in 2000, and vested the responsibility of overseeing, management and servicing of bilateral and multilateral debts, operating under the ministry of finance (Rahman, Adeola, Abiodun, \& Tolulope, 2010).

Trend of activities have revealed that Nigeria has being in long-term debt experience over the years (Festus \& Saibu, 2019). However, financing ever increasing public expenditures has been a major challenge to government and financial managers in recent times, because of the deficits in government budgets. As observed by Debt Management Office (2019), domestic debt of Nigeria has risen by 3.9\% from N15.04trn (\$49.14bn) as at 30th June, 2017 to N15.63trn ( $\$ 51.13 \mathrm{bn})$ at the end of the second quarter of 2019, making ratio of total debt to Federal government revenue trigger from $158.4 \%$ in 2015 to $258.8 \%$ in 2016 . Although declined slightly to $246.8 \%$ and $215 \%$ in 2017 and 2018 respectively, however, in 2019, it rose up to $227 \%$. Also, Director General of Chamber of Commerce Muda Yusuf, asserted that at present, Nigeria spends over N3 trillion naira to service its debt, a great opportunity cost of many public developmental projects (Yusuf, 2020). The trend of these debts and their management suggest a robbery of sustainable economic utopia, capable of reducing the standard of living, crippling employment opportunities and stirring increasing social vices in the country.

At this point, our concern is that: is debt a blessing or burden to economic growth in Nigeria? In other words, what relationship prevails between external debt and nominal GDP in Nigeria? What nature of relationship exist between domestic debt and nominal GDP in Nigeria? What influence has exchange rate on nominal GDP in Nigeria? To what extent has debt servicing influence nominal GDP? Answering these questions are important to virtually all the various economic agents, especially, policy makers who will find the response useful in decisionmaking on the best mixture of debt to employ to finance economic activities in Nigeria.

Other sections of this study are as follows. Section two presents literature review on debt and economic growth. Section three reveals methodology employed, then Section four presents the results while Section five concludes the study.

\section{Literature Review \\ 2.1. Debt}

Debts have been perceived as the monetary resources employed in an organization which is not funded by its owners but obligated to pay at an agreed period with or without interest (Oyejide, Soyede, \& Kayode, 2005). Soludo (2003) asserts that greater investments as well as greater consumption are two main classifications as well as macroeconomic motives for countries going into borrowing (specifically to finance education and health, and/or to finance transitory balance of payment deficit to lower nominal interest rates abroad, to suffice the lack of domestic long term credit or to circumvent hand budget constraint. The Keynesian economics school of thought postulates that government borrowing can be used to promote economic growth, via the financing of government deficit expenditures which stimulates aggregate demand and thus encourage increase in private investments (Mbah, 2016; Rafindadi \& Musa, 2019).

However, Okonjo, Soludo, and Muhtar (2013) contend that when the quantum of debt increases to a specific threshold, debt-servicing becomes a burden, thereby, landing most countries on the wrong side of the Debt Laffer Curve, with debt crowding out investment and growth. But, Bakare (2011) with little variance, posits that stunted growth in an economy is not a result of the country's indebtedness, rather, its inability to rationally employ the borrowed fund judiciously for economic growth and development advancement as well as efficiency in the debtservicing as envisaged. Thus, we see that debt-decision and implementation is not a burden, but failure to optimize its determined purpose frustrates the accompanied blessings.

\subsection{Debt Situation and Management in Nigeria}

It is more than a decade that the level of public debt is escalating at both domestic and international level, particularly after the financial crisis in 2008 yet without commensurate increase in growth and development (Festus \& Saibu, 2019). In 2010, 2015 and 2019, the trend of external debt stood at N689.837 billion, N2,111.510 billion and N9,022.422 billion respectively, while that of domestic debt stood at N4,551.822 billion, N8,836.996 billion and N14,272.645 billion respectively, signifying that the country depends greatly on internal sourcing of fund. 
After the debt forgiveness in 2005, much of external debts are contracted through multilateral debt, bilateral debt and euro bond. However, treasury bills, FGN bonds and treasury bonds are the major debt instruments for domestic debts. The graphical illustrations are shown below.

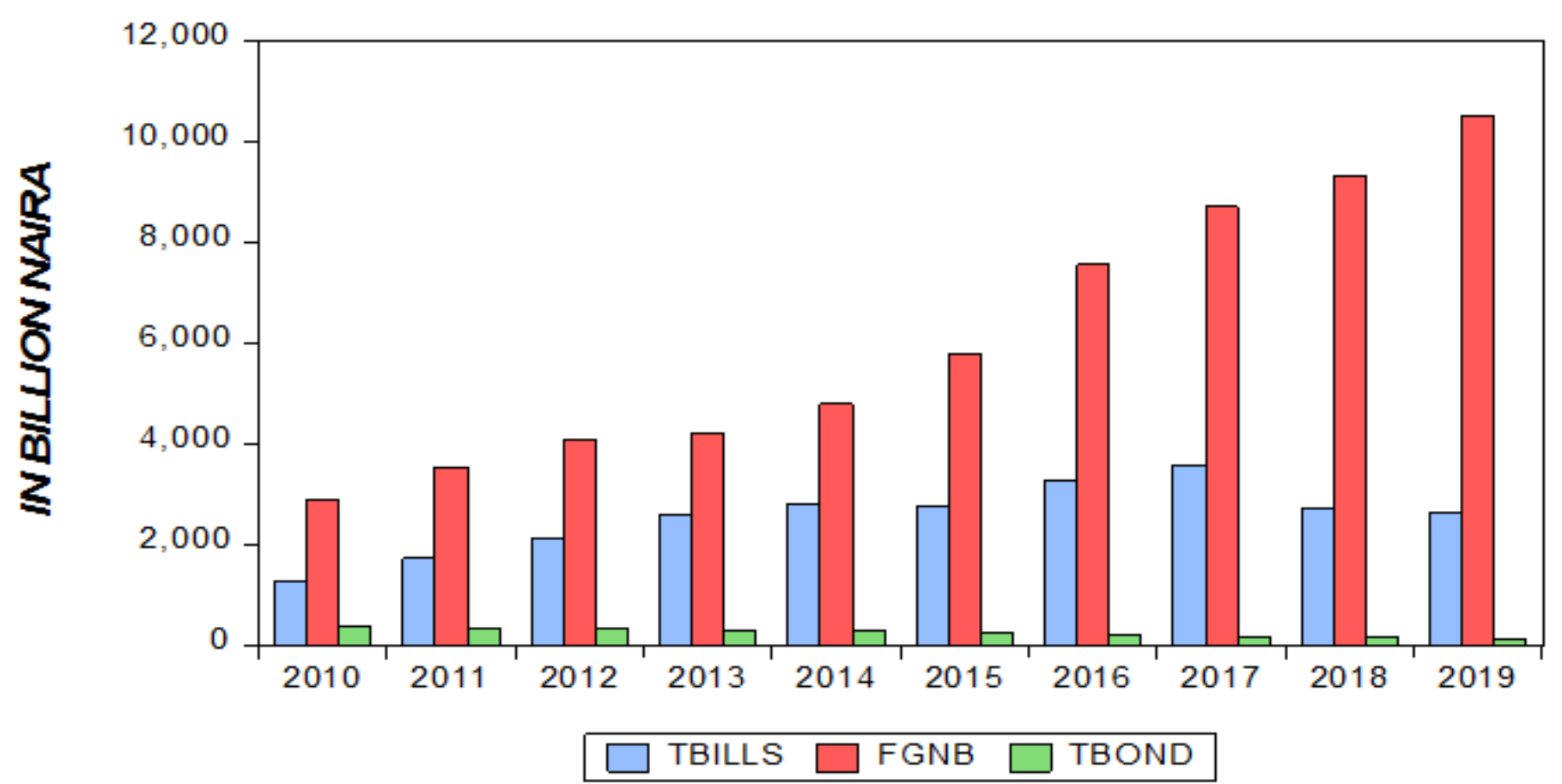

Figure-1. Graphical presentation of the trend of domestic debt instruments (treasury bills, Federal government bonds, and treasury bonds) for the period 2010 to 2019 .

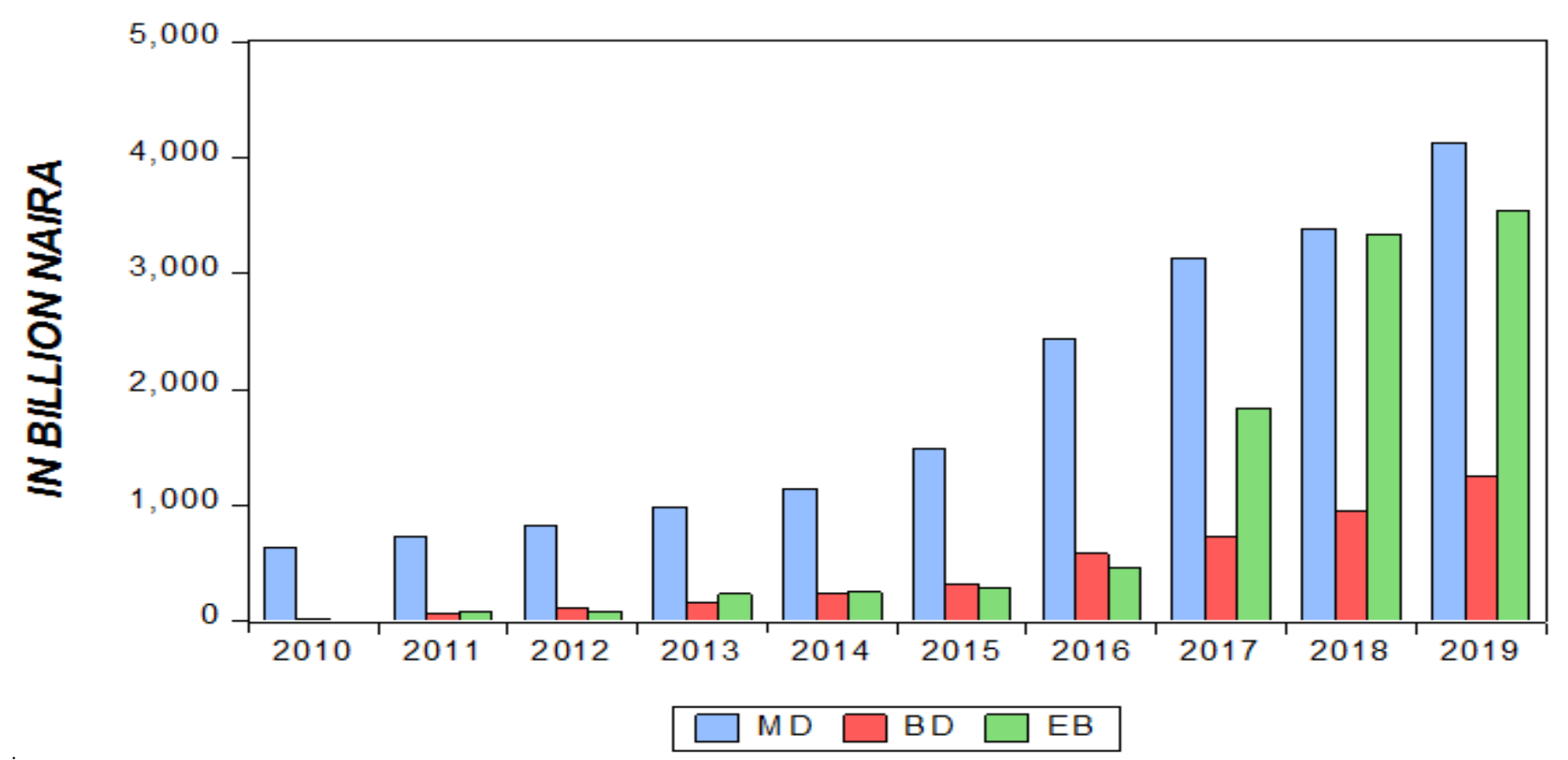

Figure-2. Graphical presentation of the trend of external debt (multilateral debts, bilateral debts, and euro bond) for the period 2010 to 2019.

Figure 1 and 2 show major components of domestic debts and external debts respectively. Within the past decade, domestic debt through federal government bond has an accelerated increased trend from N2,900 billion in 2010 to N10,500 billion in 2019. The case of treasury bills, although comparatively lower than FGNB, has been relatively stable within the period with the value of N1,200 billion and N2,600 billion in 2010 and 2019 respectively. However, treasury bonds trend appears very low with decelerated movement as N370 billion was recorded in 2010, but in 2019, only N125 billion was borrowed.

From the components of external debt, multilateral debt, bilateral debt and euro bond all possess a rightupward movement within the period (2010-2019). However, only multilateral debt is pronounced with value of N635 billion and N4,120 billion in 2010 and 2019 respectively. Bilateral debt stood at N24 billion in 2010 and $\mathrm{N} 1,250$ billion in 2019. Although Euro bond was zero naira in 2010, in 2017 and 2019, its value increased to $\mathrm{N} 1,800$ billion and N3,500 billion respectively. There is a clear indication that dependence on domestic borrowings stands taller, compared to external borrowings, nevertheless, federal government bonds and multilateral debts are their respective instruments of borrowing within the period. 


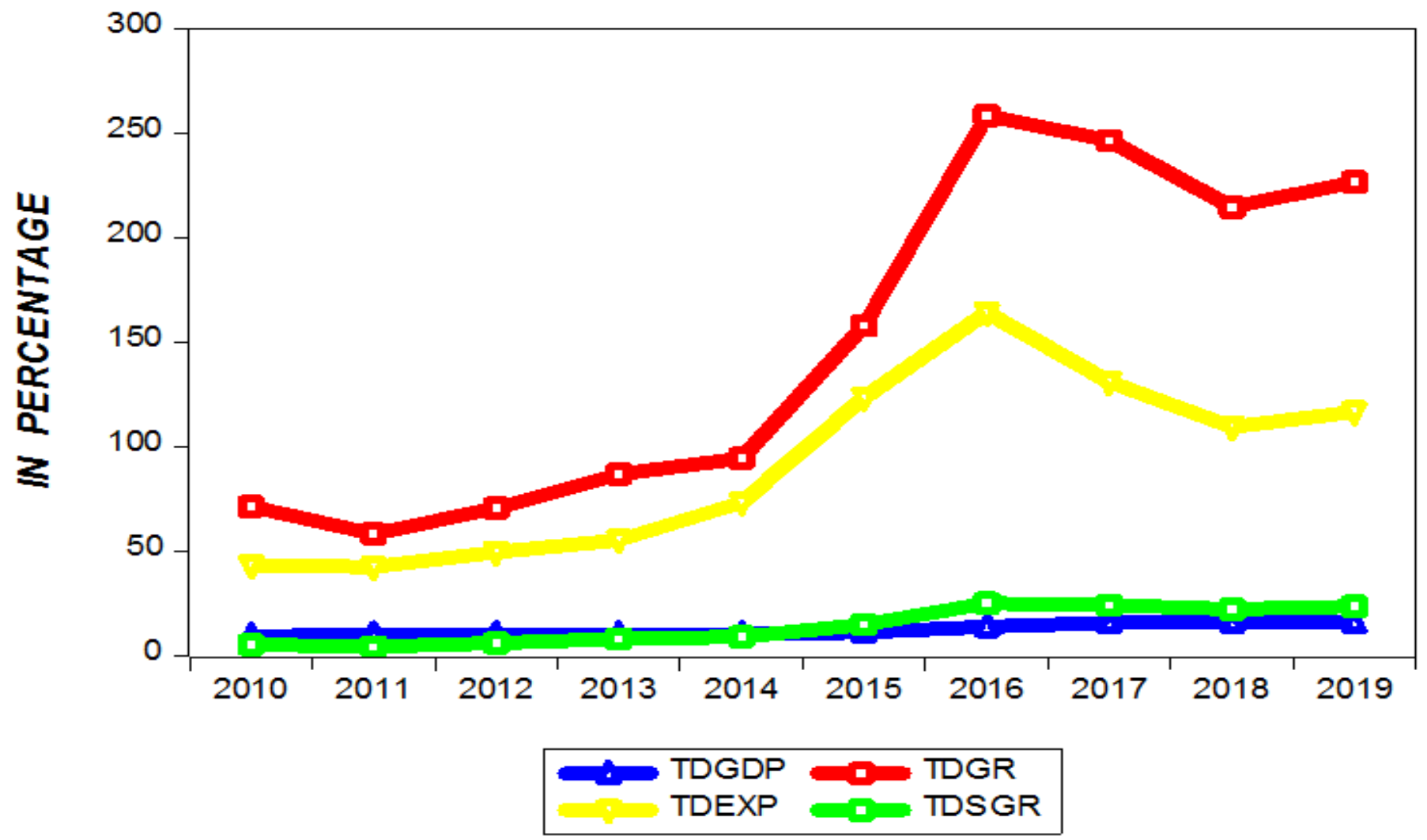

Figure-3. Graphical presentation of the trend of the ratio of total debt to GDP (TDGDP), ratio of total debt to export (TDEX), ratio of total debt to government revenue (TDGR), and ratio of total debt servicing to government revenue (TDSGR) for the period 2010 to 2019.

The ratio of total debt to GDP (TDGDP) in Figure 3 maintained a steady average trend of $10.5 \%$ from 2010 to 2015, then $14.3 \%$ in 2016 and $16.1 \%$ in 2017 to 2019. This depicts the quantum of total debt engrossed in the output level of goods and services. Also, ratio of total debt service to government revenue (TDSGR) is not far from TDGDP trend, but varied little from 2015 with a rate $15.3 \%$ and later increase sharply to $25.4 \%$ in 2016 . However, TDSGR experienced a slight fall to $24.5 \%$ in 2017 and later $22.6 \%$ which was maintained in 2018 to 2019 . This situation of TDSGR, although marginal within 2010 to 2014, the later speaks volume of government revenue consumed by debt servicing within the period.

On the other hand, the ratios of total debt to government revenue (TDGR) and to export (TDEXP) all portray parallel trends with relative gap within the period. While TDGR stood at $71.8 \%, 158.4 \%$ and $227.0 \%$, TDEXP recorded $43.6 \%, 123.8 \%$ and $117.0 \%$ in 2010,2015 and 2019 respectively. This suggests the country's great reliance on debt to finance its expenditures as well as its export, thereby, creating huge imbalance in the terms of trade as well as balance of payment.

The unconceivably increase in Nigeria's debt beyond imagination has posed great concern to citizens' welfare and economic activities, not only to the detriment of the country's image but also has mortgaged future's investment, standard of living, balance of payment, through heavy taxation. Fasoye (2018) asserts that:

The economic implications of Nigeria's rising debt profile are not only topical but also becoming provocative public debates and discourse every moment. For instance, most developing countries are submerged in the whirlpool of which significantly hinders their economic growth and development. It is also true that any economy structured and sustained by borrowing cannot achieve economic prosperity.

Although repayment of public debts could be approached through: debt rescheduling, debt equity conversion; ban on external borrowing, debt repudiation, and debt forgiveness as experienced in 2005, Rahman et al. (2010) identified scarcity of statistical data, institution arrangements; ineffective law and regulation, and low yield on debts instruments as key problems mitigating against effective management of debt in Nigeria.

\subsection{Challenges Facing Debt Management in Nigeria}

i. Instability in oil generated revenue due to global recession, vandalism, militant activities (The World Bank, 2017), and economic shut-down arising from pandemic occurrence (covid-19, natural disaster).

ii. Lack of major tax policy reforms to significantly increase non-oil revenues led to large revenue shortfalls at all levels of government (The World Bank, 2017).

iii. Multiple and high rates for foreign exchange in the country

iv. Dominant presence of corruption in public revenue allocation and expenditure (Egeonu, 2017).

v. Prodigal attitude for foreign investment and property ownership by top political leaders.

Egeonu (2017) argues that debt woes befalling the third world and African countries which Nigeria belongs, is a self-inflicted one, as most African political elites offer themselves as willing tools for exploitations in the hands of developed nations by stealing the resources of their countries and hiding them in the developed countries' banks, buying of properties and investments abroad at the detriment of their countries. Mobutu Seseseko of Zaire (DRC) was said to be richer than his country. All the looted funds were lost to the foreign nations where he hid them after his death (Egeonu, 2017). Discovery of Sani Abacha's loot of \$319 million held in United Kingdom and France (Okwumbu, 2020) and \$2.2 billion held in Switzerland (British Broadcasting Corporation, 2018) from Nigeria coffer is an indication of chronic pandemic loot by most of Nigerian leaders to enriched greatly foreign economies where this funds are being held. 


\subsection{Theoretical Underpinning}

i. Debt Overhang Theory: On debt overhang theory, Krugman (1988) posits "if there is likelihood that in the future debt will be larger than the country's repayment ability; expected debt service costs will discourage further domestic and foreign investment because the expected rate of return from the productive investment projects will be very low to support the economy as the significant portion of any subsequent economic progress will accrue to the creditor country". The theory portrays the fact that a counter-productive effect of debt instruments will severely decrease investment prospects as well as low level of output in the economy (Fasoye, 2018).

Also, Claessens and Diwan (1990) declare that "debt overhang is a situation in which the illiquidity effect, the disincentive effect, or both effects are strong enough to discourage growth in the absence of concessions by creditors." It is the inability of a country to get her debts serviced as at when due. In this respect government fails to discharge her fiscal obligations (Fasoye, 2018).

ii. Dual Gap Theory: The dual gap theory vies development as a product of investment, which is a core function of domestic savings, which is not always sufficient to finance growth and development. This calls for the government to employ available instruments for external borrowings, needed quantum of money that can be invested to spur economic activities in the country. It is believed that, the invested fund is equal with the sum that was saved. In addition, the domestic resources are to be augmented from abroad, such that we have excess of import over export (Adedoyin, Babalola, Otekunri, \& Adeoti, 2016).

As shown in national income accounting, surplus of investment over domestic saving is equal to surplus of import over export. (i.e., I-S = M-E). Thus:

Income $=$ Consumption + Import + Savings

Output $=$ Consumption + Export + Investment

Income $=$ Output

This is the basis of dual gap analysis; it explains that if the domestic saving available falls short of the level needed to realize the target rate of growth, a savings investment gap is thought to be in existent, thus borrowing is induced. On a similar note, if the maximum import requirement necessary to realize the growth target is larger than the maximum possible level of export, then there is an export-import exchange gap (Adedoyin et al., 2016).

iii. Dependency Theory: Dependency theory states that the poverty of the countries in the periphery is not only because they are not integrated or fully integrated into the world system, as it is often argued by free market economists, but because of how they are integrated into the system. From this standpoint a common school of thought is the Bourgeoisie scholars, who are of the view that the state of underdevelopment and the constant dependence of less developed countries on developed countries are as a result of their domestic mishaps. They believe this issue can be explained by their lack of close integration, diffusion of capital, low level of technology, poor institutional framework, bad leadership, corruption, mismanagement, etc (MacKinnon, Haug, \& Michelis, 1999). The proponents of this School of Thought see the underdevelopment and dependency of the third world countries as being internally inflicted rather than externally afflicted. To this school of thought, a way out of the problem is for third world countries to seek foreign assistance in terms of aid, loan, investment, etc, and allow undisrupted operations of the Multinational Corporations (Adedoyin et al., 2016).

\subsection{Empirical Review}

Debt-growth relationship has attracted many researchers' interest. Their studies are of mixed findings - both positive and negative effects of debt on economic growth. Some of these studies are reviewed.

Interesting, mixed findings from accessed extant literature could be attributed to variations in methodology, period and variables employed in the study. As observed in Table 1 above, while Adedoyin et al. (2016); Akhanolu et al. (2018); Lawrence and Victor (2016); Lucky and Godday (2017); Nwaoha et al. (2017); Omodero and Alpheaus (2019) reveal that external debt has greatly retarded economic growth, only Festus and Saibu (2019) establishes that external debt's negative influence on economic activities is nominal. However, Egbetunde (2012) and Orji (2018) show that external debts marginally favour economic activities in Nigeria.

Although, Lawrence and Victor (2016); Onakoya and Ogunade (2017) found domestic debt to have great retarded influence on economic activities, however, Akhanolu et al. (2018); Egbetunde (2012); Lucky and Godday (2017) empirically concur that domestic debt efficiently favour the output level of goods and services in Nigeria. On this note, Omotosho et al. (2016) counsels that even though, external and domestic debt favour economic activity, caution should be made to identify the threshold point at which additional debt incurred will retard economic growth. Therefore, Omotosho et al. (2016) posit that to avoid a state of quandary and onerous situation, total debt threshold level of 73.70 percent is recommended, while estimation inflexion points for external and domestic debts are 49.4 percent and 30.9 percent, respectively.

Debt servicing is not left out as some found it retarding economic activities (Egbetunde, 2012; Orji, 2018), but Omodero and Alpheaus (2019); Onakoya and Ogunade (2017) reveal it as a blessing to economic growth.

\section{Research Methodology}

The curiosity to ascertain whether the influence of Nigeria's borrowing on economic growth is a blessing or burden, has necessitated this study. As an ex-post facto design study, secondary data sourced from Central Bank of Nigeria Statistical Bulletin 2019. Upon determining that the variables were all stationary at difference 1(1) using the Augmented Dickey Fuller Unit root test, the study employs the Johansen co-integration test to ascertain the long-run integration among the variables, thereafter, regressed the model for statistical estimation of the speed of adjustment of the dependent variable in response to changes in the predictor variables, using the error correction mechanism. 
Table-1. Showing synopsis of related studies.

\begin{tabular}{|c|c|c|c|c|}
\hline $\mathbf{S} / \mathbf{N}$ & Author (s) & Study & Employed Techniques & Findings \\
\hline \multirow[t]{3}{*}{1} & \multirow[t]{3}{*}{$\begin{array}{l}\text { Egbetunde } \\
(2012)\end{array}$} & \multirow{3}{*}{$\begin{array}{l}\text { External borrowing and } \\
\text { economic growth in } \\
\text { Nigeria }(1970-2008)\end{array}$} & Ordinary Least Square & $\begin{array}{l}\text { i) External debt exerts positive but } \\
\text { insignificant influence on GDP }\end{array}$ \\
\hline & & & $\begin{array}{l}\text { ii. } \\
\text { integration test }\end{array}$ & $\begin{array}{l}\text { ii) Domestic debt exerts positive and } \\
\text { significant influence on GDP }\end{array}$ \\
\hline & & & & $\begin{array}{l}\text { iii) Presence of negative significant } \\
\text { influence of debt servicing on GDP }\end{array}$ \\
\hline \multirow[t]{2}{*}{2} & \multirow{2}{*}{$\begin{array}{l}\text { Omotosho, } \\
\text { Bawa, and } \\
\text { Doguwa } \\
(2016)\end{array}$} & \multirow{2}{*}{$\begin{array}{l}\text { Determining the optimal } \\
\text { public debt threshold for } \\
\text { Nigeria }(2005-2015)\end{array}$} & Threshold Regression & $\begin{array}{l}\text { i) Total debt threshold level of } 73.70 \\
\text { was recommended. }\end{array}$ \\
\hline & & & & $\begin{array}{l}\text { ii) The estimated inflexion points for } \\
\text { external and domestic debts were } 49.4 \\
\text { and } 30.9 \text { per cent, respectively. }\end{array}$ \\
\hline \multirow[t]{2}{*}{3} & \multirow[t]{2}{*}{$\begin{array}{l}\text { Adedoyin et al. } \\
(2016)\end{array}$} & \multirow{2}{*}{$\begin{array}{lrr}\text { External debt } & \text { and } \\
\text { economic } & \text { growth: } \\
\text { Evidence from } & \text { Nigeria } \\
(1981-2014) & \end{array}$} & $\begin{array}{l}\text { i. Auto-regression } \\
\text { Distributed Lag }\end{array}$ & $\begin{array}{l}\text { i) Presence of strong relationship } \\
\text { between external debt and economic } \\
\text { growth }\end{array}$ \\
\hline & & & $\begin{array}{l}\text { ii.Granger Causality } \\
\text { test }\end{array}$ & $\begin{array}{l}\text { ii) Absence of causality relationship } \\
\text { among the variables }\end{array}$ \\
\hline 4 & $\begin{array}{l}\text { Lawrence and } \\
\text { Victor }(2016)\end{array}$ & $\begin{array}{l}\text { Is public debt a necessary } \\
\text { factor for improving } \\
\text { economic growth? A } \\
\text { VAR modeling of the } \\
\text { Nigerian situation (1980- } \\
\text { 2014). }\end{array}$ & VAR & $\begin{array}{l}\text { i) Both external and domestic debt show } \\
\text { insignificant relationship with economic } \\
\text { growth. }\end{array}$ \\
\hline \multirow[t]{4}{*}{5} & \multirow{4}{*}{$\begin{array}{l}\text { Onakoya and } \\
\text { Ogunade } \\
(2017)\end{array}$} & \multirow{4}{*}{$\begin{array}{lrr}\text { External } & \text { debt } & \text { and } \\
\text { Nigerian } & \text { economic } \\
\text { growth } & \text { connection: } \\
\text { Evidence } & \text { from } \\
\text { Autoregressive } & \\
\text { Distributed } & \text { Lag } \\
\text { Approach (1981-2014) }\end{array}$} & $\begin{array}{l}\text { i.Auto-regression } \\
\text { Distributed Lag test }\end{array}$ & $\begin{array}{l}\text { i External debt exerts negative but } \\
\text { significant influence on GDP }\end{array}$ \\
\hline & & & $\begin{array}{l}\text { ii.Granger Causality } \\
\text { test }\end{array}$ & $\begin{array}{l}\text { ii) Domestic debt and Inflation exert } \\
\text { negative and insignificant influence on } \\
\text { GDP }\end{array}$ \\
\hline & & & & $\begin{array}{l}\text { iii) External debt service and Export } \\
\text { exert positive but insignificant influence } \\
\text { on GDP }\end{array}$ \\
\hline & & & & $\begin{array}{l}\text { iv) Unidirectional relationship prevails } \\
\text { with causality from domestic debt to } \\
\text { RGDP, and RGDP to Export. }\end{array}$ \\
\hline 6 & $\begin{array}{l}\text { Nwaoha, Ejem, } \\
\text { Egwu, Ugoji- } \\
\text { Eke, and } \\
\text { Nwabeke } \\
(2017)\end{array}$ & $\begin{array}{l}\text { An Error Correction } \\
\text { Model analysis of the } \\
\text { effect of total external } \\
\text { debt on the Nigerian } \\
\text { economy }(1980-2015)\end{array}$ & i. ECM & $\begin{array}{l}\text { i) External debt exerts negative but } \\
\text { significant influence on GDP }\end{array}$ \\
\hline \multirow[t]{2}{*}{7} & \multirow[t]{2}{*}{$\begin{array}{l}\text { Lucky and } \\
\text { Godday }(2017)\end{array}$} & \multirow{2}{*}{$\begin{array}{l}\text { The Nigeria debt } \\
\text { structure and its effects } \\
\text { on economic performance } \\
(1990-2015)\end{array}$} & \multirow[t]{2}{*}{ i. OLS } & $\begin{array}{l}\text { i) External debt exerts negative but } \\
\text { significant influence on GDP }\end{array}$ \\
\hline & & & & $\begin{array}{l}\text { ii) Domestic debt exerts positive and } \\
\text { significant influence on GDP }\end{array}$ \\
\hline \multirow[t]{2}{*}{8} & \multirow[t]{2}{*}{ Orji (2018) } & \multirow[t]{2}{*}{$\begin{array}{l}\text { The effect of foreign debt } \\
\text { on the economic growth } \\
\text { of Nigeria (1995-2017) }\end{array}$} & \multirow[t]{2}{*}{ i. OLS } & $\begin{array}{l}\text { i) There is presence of positive } \\
\text { insignificant influence of external debt } \\
\text { on Nigerian GDP. }\end{array}$ \\
\hline & & & & $\begin{array}{l}\text { ii) Foreign debt servicing exerts } \\
\text { negative and insignificant influence on } \\
\text { GDP }\end{array}$ \\
\hline \multirow[t]{2}{*}{9} & \multirow{2}{*}{$\begin{array}{l}\text { Akhanolu, } \\
\text { Babajide, } \\
\text { Akinjare, } \\
\text { Tolulope, and } \\
\text { Godswill } \\
\text { (2018) }\end{array}$} & \multirow{2}{*}{$\begin{array}{l}\text { The effect of public debt } \\
\text { on economic growth in } \\
\text { Nigeria: An empirical } \\
\text { investigation } \\
\text { 2017) }\end{array}$} & \multirow[t]{2}{*}{$\begin{array}{l}\text { i. Two-Stage Least } \\
\text { Square }\end{array}$} & $\begin{array}{l}\text { External debt shows negative } \\
\text { significant impact on GDP }\end{array}$ \\
\hline & & & & $\begin{array}{l}\text { ii) Domestic debt positively and } \\
\text { significantly impacts on GDP }\end{array}$ \\
\hline \multirow[t]{2}{*}{10} & \multirow{2}{*}{$\begin{array}{l}\text { Omodero and } \\
\text { Alpheaus } \\
(2019)\end{array}$} & \multirow{2}{*}{$\begin{array}{l}\text { The effect of foreign debt } \\
\text { on the economic growth } \\
\text { of Nigeria (1997-2017) }\end{array}$} & \multirow[t]{2}{*}{ i. OLS } & $\begin{array}{l}\text { i) Foreign debt exerts a negative } \\
\text { significant influence on nominal GDP }\end{array}$ \\
\hline & & & & $\begin{array}{l}\text { ii) Foreign debt servicing has a strong } \\
\text { and significant positive impact on } \\
\text { nominal GDP }\end{array}$ \\
\hline 11 & $\begin{array}{l}\text { Festus and } \\
\text { Saibu (2019) }\end{array}$ & $\begin{array}{l}\text { Effect of external debt on } \\
\text { Nigerian economy: } \\
\text { further evidences (1981- } \\
2016)\end{array}$ & i. ARDL & $\begin{array}{l}\text { i) External debt contributes negatively } \\
\text { and insignificantly to growth in Nigeria }\end{array}$ \\
\hline
\end{tabular}

In line with our research questions, external debt, domestic debt, total debt servicing, and exchange rate are used to proxy the Nigerian debt. While nominal GDP is used to measure growth (the explained variable). Reason for nominal GDP is because of its non-deflated nature to match with the non-deflated predictor variables employed in the study as recommended by Bhole (2006). Also, adapting from the model of Omodero and Alpheaus (2019) with little modification, the functional relationship is given as:

Economic Growth $=\mathrm{f}(\mathrm{Debt})$

NGDP $=\mathrm{f}($ EDS, DDS, TDS, EXR)

The equation is transform into econometric form with logarithm taken to transform the data. Thus:

$\mathrm{LnNGDP}=\beta_{0}+\beta_{1} \operatorname{lnEDS}+\beta_{2} \operatorname{lnDDS}+\beta_{3} \ln \mathrm{TDS}+\beta_{4} \mathrm{EXR}+\mu$ 
Where:

NGDP = Nominal Gross Domestic Product.

EDS = External Debt Stock.

DDS $=$ Domestic Debt Stock.

TDS $=$ Total Debt Servicing.

EXR = Exchange Rate, as the controlling variable.

$\mathrm{Ln}=$ logarithm

$\beta_{0},=$ constant parameter

$\beta_{1}, \beta_{2}, \beta_{s}, \boldsymbol{\beta}_{4}=$ Coefficients or Parameters

$\mu=$ error term

A priori Expectation: $\beta_{1}>0, \beta_{2}>0, \beta_{3}<0, \beta_{4}<0$.

\section{Presentation and Analysis of Result}

\subsection{Unit Root Tests}

The unit root test was conducted in the study to ascertain the statationarity of the variables using the Augmented Dickey-Fuller (ADF) test. The result of the unit root test is shown in Table 2 below:

Table-2. ADF stationarity (unit root) test result.

\begin{tabular}{c|c|c|c|c}
\hline Variable & ADF test statistic & Critical Value 5\% & Order of Integration & Prob. \\
\hline $\ln$ NGDP & -3.208552 & -2.943427 & $\mathrm{I}(1)$ & 0.0274 \\
\hline $\ln$ EDS & -4.725971 & -2.943427 & $\mathrm{I}(1)$ & 0.0005 \\
\hline $\ln$ DDS & -4.566508 & -2.943427 & $\mathrm{I}(1)$ & 0.0008 \\
\hline $\ln$ TDS & -7.885127 & -2.943427 & $1(1)$ & 0.0000 \\
\hline EXR & -5.218774 & -2.943427 & $1(1)$ & 0.0001 \\
\hline
\end{tabular}

Note: Critical Values at $5 \%$ is Considered Significant.

The ADF Unit root result in Table 2 shows that all the variables became stationary at first difference given that the ADF statistic value for each of the variables is greater than the critical values in absolute terms and at $5 \%$ level of significance. On the basis of this result we proceed to estimate the presence or other wise of long-run relationship among the variables using Johansen co-integration test.

\subsection{Co-Integration Test}

Having established that the variables are integrated at order one 1 (1), we tested for the existence of long run relationship among the variables using the Johansen multivariate co-integration analysis based on trace test and maximum eigenvalue test. The result of the co-integration test is presented in Table 3 below:

\begin{tabular}{c|c|c|c|c}
\multicolumn{6}{c}{ Table-3. Johansen co-integration test result. } \\
\hline Hypothesized & & Trace & 0.05 & \\
\hline No. of CE(s) & Eigenvalue & Statistic & Critical Value & Prob.** \\
\hline None $*$ & 0.674751 & 108.4297 & 88.80380 & 0.0010 \\
\hline At most 1 $*$ & 0.504033 & 67.99589 & 63.87610 & 0.0216 \\
\hline At most 2 & 0.456190 & 42.75104 & 42.91525 & 0.0519 \\
\hline At most 3 & 0.309821 & 20.82145 & 25.87211 & 0.1871 \\
\hline At most 4 & 0.187443 & 7.472483 & 12.51798 & 0.2978 \\
\hline
\end{tabular}

Note:

Trace test indicates 2 cointegrating eqn(s) at the 0.05 level.

* denotes rejection of the hypothesis at the 0.05 level.

**MacKinnon et al. (1999) p-values.

From Table 3, the result of the Johansen's co-integration analysis based on trace statistics shows two cointegrating equations which imply that the variables are co-integrated and that significant long-run relationship exists between the various determinants of debt and economic growth in Nigeria. We therefore reject the null hypothesis of no co-integration and proceed to determine the adjustment for the discrepancies between the longrun and short-run interaction of the times series using error correction estimation mechanism.

\subsection{Error Correction Mechanism}

The error correction mechanism (ECM) is used in this study to determine the speed or rate at which the dependent variable will adjust to changes in the independent variables. The error correction mechanism result is therefore presented in Table 4 .

Table-4. Error correction estimate output for the model.

\begin{tabular}{|c|c|c|c|c|}
\hline \multicolumn{5}{|c|}{ Dependent Variable: $\ln N G D P$} \\
\hline $\operatorname{ECM}(-1)$ & -0.064848 & 0.02468 & -2.62790 & 0.0095 \\
\hline $\mathrm{D}$ (LNEDS) & 0.022417 & 0.03298 & 0.67973 & 0.4978 \\
\hline $\mathrm{D}(\mathrm{LNDDS})$ & 0.196333 & 0.09803 & 2.00289 & 0.0471 \\
\hline $\mathrm{D}(\mathrm{TDS})$ & -0.054643 & 0.03435 & -1.59060 & 0.1139 \\
\hline $\mathrm{D}(\mathrm{EXR})$ & 0.000133 & 0.00065 & 0.20506 & 0.8378 \\
\hline Constant & 0.100733 & 0.03656 & 2.75519 & 0.0066 \\
\hline R-Squared & 0.576090 & \multicolumn{2}{|c|}{ Log likelihood } & 47.07051 \\
\hline Adj. $\mathrm{R}^{2}$ & 0.473767 & \multicolumn{2}{|c|}{ Akaike Info Criterion } & -2.111919 \\
\hline Sum Sq. resid & 0.170110 & \multicolumn{2}{|c|}{ Schwarz Criterion } & -1.763613 \\
\hline S. E. equation & 0.076589 & \multicolumn{2}{|c|}{ Mean dependent Var } & 0.184750 \\
\hline F-Statistic & 5.630111 & \multicolumn{2}{|c|}{ S.D. dependent Var } & 0.105579 \\
\hline Prob. (F-stat) & 0.000052 & \multicolumn{2}{|c|}{ Durbin-Watson stat } & 2.010592 \\
\hline
\end{tabular}


From the ECM result presented in Table 4 above, the coefficient of -0.064848 shows that the error correction term is correctly signed and significant, implying that the discrepancies between the short-run and long-run equilibrium can be corrected each year by the tone or speed of 6.5 percent. The F- statistics with the p-value of 0.000052 shows that the regression is statistically significant and the model has a good fit. The coefficient of determination of 0.576090 shows that about 57.6 percent of the total variation in economic growth as proxied by nominal GDP is jointly explained by the variation in debt variables within the study period while the remaining 42.4 percent variation is attributed to other factors not included in the model. This implies that debt determinants exhibited an average power in explaining the variations in the growth of Nigerian economy.

Analysis of the short- run estimates showed that while total debt servicing exert negative influence, external debt stock, domestic debt stock and exchange rate have positive relationship with nominal GDP in Nigeria within the study period to the extent that a one percent increase in EDS, DDS and EXR, all things being equal will increase the output level of goods and services in Nigeria by 0.02, 0.19 and 0.00 percent respectively. However, domestic debt stock does not only exert positive influence but also significantly influence economic activities in Nigeria.

The implication of the result is that domestic debt stock is the only proficient borrowing source that drive the output level of goods and services in Nigeria, thereby spurring economic growth and development in terms of employment generation and improvement in standard of living. All the explanatory variables' results comply to the a priori expectations with exception to exchange rate, which showed a positive but marginal relationship with nominal GDP in Nigeria. This could be attributed to Nigeria's largest export of crude oil to the United States accounting over $80 \%$ of trade transactions from Nigeria (Okoro \& Charlse, 2019). This finding agrees with the a priori expectations, and is consistent with previous studies by Egbetunde (2012) and Orji (2018) where the coefficient values of external debts were positive and debt servicing signed in negative and all insignificantly impact on the economic growth. The study also finds credence to the studies of Akhanolu et al. (2018); Lucky and Godday (2017) where, domestic debt was found to efficiently promote the output level of goods and services in Nigeria during the evaluation period.

\section{Concluding Remarks and Policy Recommendations}

This paper that set out to empirically examine the Nigeria's debt-growth nexus: whether a blessing or burden for the period 1981-2019, and adopted the Augmented Dickey- Fuller unit root test, co-integration analysis and error correction model estimation techniques. From the ECM results, it is obvious that debt financing in Nigeria is a blessing as external and domestic debt stocks all exert positive influence on economic growth. However, only domestic debt stock is efficient enough to spur economic activities, which suggests that prudent employment of domestic debt which is not affected by exchange rate is a strong catalyst for rapid increase in economic activities in Nigeria. Therefore, having identified domestic debt as the linchpin of economic growth in Nigeria, the study recommends the choice for internally borrowed fund as the best benign financing option as well as its optimal utilization for meaningful commensurate economic activities. Also, recommendable threshold point of borrowing should strictly be adhere to in order to avoid landing the economy into a state of onerous situation.

\section{References}

Adedoyin, L. I., Babalola, B. M., Otekunri, A. O., \& Adeoti, J. O. (2016). External debt and economic growth: Evidence from Nigeria. OECONOMICA, 12(6), 179-194.

Adepoju, A. A., Salau, A. S., \& Obayelu, A. E. (2007). The effects of external debt management on sustainable economic growth and development: Lessons from Nigeria. Munich Personal RePEc Archive, 2147, 1-30.

Akhanolu, I. A., Babajide, A. A., Akinjare, V., Tolulope, O., \& Godswill, O. (2018). The effect of public debt on economic growth in Nigeria: An empirical investigation. International Business Management, 12(6), 436-441.

Bakare, A. (2011). The macroeconomic impact of foreign aid in Sub-Saharan Africa: The case of Nigeria. Business and Management Revierw, $1(5), 24-32$.

Bhole, L. M. (2006). Financial institutions and markets. New Delhi: Tata McGraw-Hill.

Bhole, L. M. (2006). Financial institutions and markets. New Delhi: Tata McGraw-Hill.
British Broadcasting Corporation. (2018). Abacha loot to be given to poor Nigerians. Retrieved from: https://www.google.com/amp/s/www,bbc.com/news/amp/world-africa-44654931? espv=1.

Claessens, S., \& Diwan, I. (1990). Investment incentives: New money, debt relief, and the critical role of conditionality in the debt crisis. The World Bank Economic Review, 4(1), 21-41.Available at: https://doi.org/10.1093/wber/4.1.21.

Debt Management Office. (2019). Nigeria's public debt stock as at December 31, 2019. Nigeria: Debt Management Office.

Egbetunde, T. (2012). External borrowing and economic growth in Nigeria. Fountain Journal of Management and Social Sciences, 1(1), 1-9.

Egeonu, P. C. (2017). Third world dependency, theoretical assumptions and African underdevelopment: Acritique analysis. Online Journal of Arts, Management and Social Sciences, 2(2), 16-28.

Fasoye, K. (2018). Nigeria's domestic debt profile (1980 - 2017). Historical Research Letter, 47, 9-14.

Festus, G. E., \& Saibu, M. O. (2019). Effect of external debt on Nigerian economy: Further evidences. Munich Personal RePEc Archive, 29704, 1.21

Krugman, P. (1988). Financing vs. forgiving a debt overhang. Journal of Development Economics, 29(3), 253-268.Available at: https://doi.org/10.1016/0304-3878(88)90044-2.

Lawrence, U. E., \& Victor, E. O. (2016). Is public debt a necessary factor for improving economic growth? A VAR modeling of the Nigerian situation. IOSR Journal of Business and Management, 18(6), 1-11.

Lucky, E. U., \& Godday, O. O. (2017). The Nigeria debt structure and its effects on economic performance. International Journal of Business and Management Review, 5(10), 79-88.

MacKinnon, J. G., Haug, A. A., \& Michelis, L. (1999). Numerical distribution functions of likelihood ratio tests for cointegration. Journal of Applied Econometrics, 14(5), 563-577.Available at: https://doi.org/10.1002/(sici)1099-1255(199909/10)14:5<563::aidjae530>3.0.co;2-r.

Mbah. (2016). Impact of external debt on economic growth in Nigeria: An ARDL bound testing approach. Paper presented at the Proceedings of the Fifth Middle East Conference on Global Business Economics, Finance and Banking (ME16Dubai October Conference) ISBN: 9781-943579-27-3 Dubai-UAE. 14-16 October. Paper ID: DF601.

Ngassam, C. (2000). Sub-Saharan Africa's debt crisis: Analysis and forecast based on Nigeria. Managerial Finance, 32(7), 606-620.

Nwaoha, W. C., Ejem, W. C., Egwu, C. A., Ugoji-Eke, P. N., \& Nwabeke, C. E. (2017). An error correction model analysis of the effect of total external debt on the Nigerian economy (1980-2015). International Journal of Economics and Financial Research, 3(8), 119-129.

Okonjo, N., Soludo, C. C., \& Muhtar, M. (2013). The debt trap in Nigeria: Towards a sustainable debt strategy (pp. 23-74). New York USA: African World Press.

Okoro, C. U., \& Charlse, F. B. (2019). Naira exchange rate variation and nigeria economic growth: A time series study. American Economic \& Social Review, 5(2), 21-30.Available at: https://doi.org/10.46281/aesr.v5i2.360. 
Okwumbu, R. (2020). Boom: Nigeria's total debt portfolio hits at N27.4 trillion. Retrieved from: https://nairametrics.com/2020/04/02/nigeria-total-debt-portfolio-hits-at-n27-4-trillion-as-at-end-of-2019/.

Omodero, C. O., \& Alpheaus, O. E. (2019). The effect of foreign debt on the economic growth of Nigeria. Management Dynamics in the Knowledge Economy, 7(3), 291-306.

Omotosho, B. S., Bawa, S., \& Doguwa, S. I. (2016). Determining the optimal public debt threshold for Nigeria. CBN Journal of Applied Statistics, 7(2), 1-25.

Onakoya, A. B., \& Ogunade, A. O. (2017). External debt and Nigerian economic growth connection: Evidence from autoregressive distributed lag approach. Journal of Economics and Development Studies, 5(1), 66-78.Available at: https://doi.org/10.15640/jeds.v5n1a7.

Orji, O. (2018). The effect of foreign debt on the economic growth of Nigeria. Journal of Accounting and Financial Management, 4(4), 22-29.

Oyejide, T. A., Soyede, A., \& Kayode, M. O. (2005). Nigeria and IMF (Vol. 1, pp. 2-4). Ibadan: Heinemann Publication.

Rafindadi, A. A., \& Musa, A. (2019). An empirical analysis of the impact of public debt management strategies on Nigeria's debt profile. International Journal of Economics and Financial Issues, 9(2), 125-137.

Rahman, Y. B., Adeola, I. K., Abiodun, O. M., \& Tolulope, A. O. (2010). Debt management and economic growth in Nigeria: Performance, challenges and responsibilities. Information Management, 12, 31-40.

Soludo, C. C. (2003). Debt poverty and inequality: Towards an Exit Strategy for Nigeria and Africa. In: Okonjo, N., Soludo, C.C., \& Muhtar, M. (2013). The debt trap in Nigeria: Towards a sustainable debt strategy (pp. 23-74). New York USA: African World Press.

The World Bank. (2017). Nigeria bi-annual economic update: Fragile recovery. International Bank for Reconstruction and Development, 1-49.

Yusuf, M. (2020). Nigerian debt profile: Economic sustainability plan. Channels Television Nigeria. Retrieved from: https://m.youtube,com/watch?index=1 10\&list=PL161vhbhEqwzxIUjZuxolaEkD6FtAIWac\&v=sH9tRraBrdk. 